This is the accepted manuscript of the article, which has been published in

Scandinavian Political Studies. 2019.

https://doi.org/10.1111/1467-9477.12150

\title{
The Finnish parliamentary election of 2019: results and voting patterns
}

\section{Sami Borg}

Tampere University

This article begins with an overview of the Finnish party and electoral systems. It proceeds to outline the results of the 2019 general election and then evaluates some main reasons for the outcome. Finally, it analyses the socio-demographic patterns of party support. Lauri Karvonen $(2014,44-47)$ has described the features of the Finnish political parties and the challenges facing them. Generally, if established parties are able to cope with the changing socio-economic structures and political issues over time, they will survive and succeed in limiting the popularity of new political groups. Based on the findings of Gallagher et al. (2011) relating to 16 West European democracies, Karvonen $(2014,44)$ notes that from the 1960s to 2009 support for new parties grew remarkably in Finland, as in most of the other 15 countries. Between the 1990s and 2010, about one fifth of the voters backed new parties in Finnish parliamentary elections and this was close to the average in the 16 countries covered by the Gallagher study.

\section{Party system change in Finland}

Figure 1 presents the support for the political parties in general elections between 1945 and 2019. In a longer perspective it was important for the Finnish Social Democratic Party (SDP) to recover rapidly from the split in its ranks at the turn of 1950s and 1960s (Karvonen 2014, 45) since this helped the party consistently to gain the largest share of the parliamentary vote between 1945 and 1999. There were only two exceptions - in 1966 and in 1991 - when the Centre became the leading party. Equally, the largest vote-share in post Second World War Finland has usually meant under 25 per cent support, and always under 30 per cent. Until late 1990s, Finland fitted in well with the 
Nordic model in which social democrats have had a consistent and dominant role in the political arena (Arter 2015a, 63-). This is no longer the case in the new millennium.

\section{Figure 1 here}

While the SDP has suffered from the decreasing number of working class voters and a weakening of their identification with leftist parties, the changing economic structure of Finnish society has challenged the Centre party as well. In today's Finland, only four per cent of the working-age population are employed in the primary sector (farming, forestry, fisheries) and it is this group that has been one of the cornerstones of support for the Centre party and its predecessor, the Agrarian Party. The Centre Party has also been challenged by populist parties. Despite the emergence in the late 1950 s of an Agrarian splinter party, the Finnish Rural Party, the Centre Party has managed to reformulate its agenda and re-anchor its support more generally in defence of the interests of rural regions (Arter 1999).

Since the 1970s a moderate right-wing party, the National Coalition, has also belonged to the group of larger parties in Finland. Ideologically, the National Coalition used to be a conservative right-wing party and many previous studies have labelled it as such (Pesonen \& Riihinen 2002; Arter 2015b; Karvonen 2014). How ever, the party is not that conservative anymore. Nowadays its party platforms (Paloheimo 2008) and voters (Westinen 2015) seem to hold quite liberal views on many political issues. The changing economic structure of Finnish society has gradually favoured the National Coalition, as white-collar groups and other economically prosperous persons are typical supporters and candidates.

The growing appeal of the SDP contributed to undercutting support for extreme leftist views among the Finnish electorate during 1960s, and especially since mid-1970s. At the 1983 general election, support for the communist dominated Finnish People's Democratic League dropped to 13.5 per 
cent, and at the end of the same decade, at the time of the collapse of the Soviet Union, the party was reborn as the Left Alliance with a non-communist platform. Since then the party has gained about 7-11 per cent of votes in parliamentary elections. During the second half of the 1980s, the green movement started to grow and operate as a registered political party. In the general election between 1991 and 2015, the Greens managed to stabilize their share of votes at around 7-8 per cent, overtaking the Left Alliance at the 2015 elections.

Two smaller parties have regularly gained a handful of Eduskunta seats. Electoral support for the Swedish People's Party is mainly grounded in the Swedish-speaking minority. The size of this minority has been declining slowly and stands today at about five per cent of the population. In the order of two-thirds of those belonging to the language minority voted for the SPP in the 2015 parliamentary elections (FSD3067). As the party also gets some votes from the Finnish-speaking population, it has contrived about 4-5 per cent support over recent decades. In addition, a small Christian party was established in the mid-1960s. Since mid-1970s the Christian Democrats have attracted about 3-4 per cent of the vote in parliamentary elections.

Finally, when viewing the growth and decrease curves of the parties' long-term electoral support, the populist Finns Party and its forerunner the Finnish Rural Party stand out. In 1970 and 1983, the Rural Party gained about 10 per cent of the vote but, typically for populist parties, its support proved ephemeral. After the Rural Party went bankrupt in the mid-1990s, a new party, the True Finns, was established to continue Rural Party's populist line. Thanks to the absence of a formal electoral threshold, the party survived as a miniscule parliamentary party at the 1995, 1999 and 2003 elections with under two per cent national support. The third populist support wave took place at the 2011 general election when the True Finns contrived no less than 19 per cent of the vote, increasing its support by an unprecedented 15 percentage points compared with four years earlier. 


\section{The 2019 general election: the result}

On Sunday April 142019 votes were cast in the 12 mainland multi-member districts and the singlemember Åland Islands. There were 2468 candidates, of whom 42 per cent were women and 52 per cent men. The number of women elected was a record high of $47 \%$. Turnout was 72.1 per cent, an advance of 2.0 percentage points compared with the 2015 election. For Finns living abroad, the turnout was substantially lower at only 12.6 per cent. This was the first time that foreign-based Finns could use the advance postal voting facility. However, it does not appear to have had any major impact on their turnout as it increased only 2.5 percentage points from 2015 (Statistics Finland 2019). The turnout for all eligible voters was 68.7 per cent and, according to a comprehensive voter turnout database (IDEA 2019), this figure placed Finland $21^{\text {st }}$ among 55 European countries, languishing far behind the other Nordic countries in the most recent parliamentary elections (Sweden 2018/ 87.2\%; Denmark 2015/85.9\%; Iceland 2016/79.2\%; Norway 2017/78.2\%). Interestingly, in 2019 more than half of Finnish voters (50.7\%) cast a ballot before the designated date of the election. Advance voting became popular in the early 1990s, not least because in 1991 Finland shifted from two ordinary election days to a single polling day. Between 1991 and 2015 about 40-47 per cent of voters at parliamentary elections have cast their votes in advance polling stations, and in 2019, they formed the majority for the first time.

Finland employs an open-list proportional electoral system with mandatory preferential voting (see Nurmi's contribution to this symposium). Citizens are obliged to vote for one candidate and one candidate only (von Schoultz 2018). A straightforward ballot structure means that a vote for a candidate is also automatically a vote for the party the candidate represents. Each candidate belongs to a list of a registered political party, or to an ad hoc non-party list of candidates. Within a party or other group, the candidate with the most votes ranks first on the list, the candidate with second most votes second etc. The allocation of votes into seats is based on the d'Hondt system. 
Each district functions as a separate sub-unit and there are no national adjustment seats. In 2019 the district magnitude - the allocation of seats per district - ranged from 7 to 36 in the 2019 elections. The system favours the larger parties and affects proportionality especially in the smallest districts.

Table 1 sets out the result of the 2019 general election. The result was unprecedented since none of the political parties managed to gain over 18 per cent of the vote. Until the very end of the counting in the 12 districts, the Social Democrats, Finns Party, and National Coalition were running neck and neck to become the largest parliamentary party and so gain the right to initiate negotiations on the formation of a new government. All three parties increased the number of their seats compared to the 2015 elections, but only the Social Democrats increased their support in terms of vote-share. Six extra seats helped the Social Democrats to become the largest party with 40 M Ps, followed by the Finns Party (39) and National Coalition (38).

Table 1 here

For the Centre Party, the result was as catastrophic as in 2011 and this was the first time its support had fallen below 15 per cent. Its position as the 'prime minister party' clearly contributed to the loss of seats, and a fall in support of 7.3 percentage points compared with the 2015 election. History repeated itself since from the 2007 to 2011 general election the drop in support was almost the same: -16 seats and -7.3 percentage points.

Climate change and immigration dominated the election campaign whereas the economy and employment were discussed less frequently than in previous elections. The need for action to 
combat climate change was also extensively covered in individual candidate campaigns. Accordingly, it was not a big surprise that the Greens achieved their best-ever result in a Finnish parliamentary election ( +5 seats and +3.0 percentage points). Climate change issues also seemed to benefit the Left Alliance since the party campaigned on much the same 'green agenda' as the Greens. As usual, support for the Swedish People's Party and the Christian Democrats did not show any major variation compared with earlier. Both have loyal supporters who are active in turning out to vote.

As to the 'winning' SDP, Finnish electoral trends highlight the way the main opposition party usually picks up support at general elections, although this was not the case in 2011 and 2015 due to the Finns Party gains. During the electoral period 2015-2019, the SDP managed to take advantage of the severe problems the incumbent centre-right coalition experienced in seeking to implement a root-and-branch reform of the health and social care system (see Raunio's article). The SDP managed to sell the obvious threats posed by the reform to potential supporters.

For the Finns Party, the election result was more than satisfactory in the circumstances. The party entered government for the first time after the 2015 election and this quickly led to a loss in support. Then, at the beginning of 2017, the long-term party chair Timo Soini announced he would step down as party leader at the forthcoming party conference. Soini, the foreign secretary, backed his colleague Sampo Terho but the party congress voted in favour of Jussi Halla-aho, a member of the European parliament. Halla-aho had a reputation for holding much harder-line anti-immigrant views and differed from Soini in many other issues too. As a consequence of Halla-aho's election, the governing partners of the Finns Party, the Centre and National Coalition, declared that they would not continue in coalition with the Finns Party. The matter was 'resolved' in a highly unusual fashion. Over half the Soini wing of the party broke away and formed a new group, ultimately called Blue 
Reform which remained in government whilst the Halla-aho-led Finns Party was consigned to opposition. The Blue Reform ran candidates across the board in 2019, including four of their outgoing ministers, but to scant avail. The Blue Reform failed to claim a single seat and managed a miserly 1.0 per cent of the nation al vote.

In contrast, the Finns Party began to increase its support in the opinion polls over the last quarter of 2018. It is very likely that this reflected the extensive media coverage of sex-related crimes committed by immigrants whose victims were young teenage girls. The Finns Party exploited the news to good effect and the party's standing in the opinion polls rose at the turn of 2018 and 2019. Closer to the election, the Finns Party also positioned itself against almost all other parliamentary parties in the debates on climate change. The Finns Party message was that Finland did not need to rush into action since many other countries were far more culpable of causing the problem. Clearly, some sections of the electorate responded positively to such views.

\section{The socio-demographic profile of party support}

Table 2 describes the socio-demographic structure of each parties' supporter groups whilst table 3 rotates percentages from columns to rows in order to analyse the party support in different population groups. The best data available for these purposes are pooled polling data, even though they do not correspond exactly with the election results for all political parties. In the post-election surveys used in national election studies ${ }^{1}$, the number of respondents is not large enough to carry out sufficiently reliable analysis, especially in relation to smaller societal groups. However, the Telebus data, provided by the Taloustutkimus polling institute are based on quota sampling from the voting age population (gender, age and region), and collected between M arch 4 and M ay 19 in 
2019. In total, 4693 of the 6857 survey respondents (68.4\%) declared which party they would vote for, if parliamentary elections were held today.

As table 2 indicates, three of the eight established parliamentary parties have a clear overrepresentation of men or women among their voters. About two-thirds of Christian Democrat voters are women whilst in the Green Party and Finns Party the gender distribution is even more skewed. Over 70 per cent of Green Party supporters are women, whereas in the Finns Party over 70 per cent are men.

The contrast between the Greens and Finns Party is not limited to gender. When looking at the education level of their supporters, the share of voters with no or short vocational education is largest in the Finns Party, while the share of highly educated is largest in the Greens. Most interestingly, table 3 shows clearly that in today's Finland, these two relatively young parties ${ }^{1}$ are polarizing the Finnish party system in a new way. True, for elections, both parties still have major problems in getting all their supporters out, but in the opinion polls they are strikingly dominant in many population groups. The Finns Party is the most popular party among men and among the least educated voters whereas the Greens are the leading party among women, in the under-50 age cohorts and among the highly educated.

Table 2 here

Table 3 here 
As table 3 documents, aside from the Greens and the Finns Party, the SDP is the only party able to boast being the most popular party among the voter groups under study. According to pooled party support polls from March to M ay in 2019, the SDP was the largest party among the 50-64 year old voters, and especially among the oldest voters. SDP is also favoured most frequently by voters with the lowest education level, which goes along with the high average age of SDP's supporters.

\section{Conclusions}

The historic Finnish parties have generally struggled to maintain their support in recent parliamentary elections. Particularly over the last decade they have been confronted with major new challenges. Given the ageing of their supporters, the future of the Social Democrats and Centre does not look all that bright. The same structural problem applies also to the Swedish People's Party and Christian Democrats. All four parties have much to do in trying to win new supporters in the forthcoming elections.

As elsewhere, the prospects for the Finnish left-wing parties (the Left Alliance and the Social Democrats) are clouded by the diminishing number of working class voters and those that identify with the working class. In view of its socio-economic profile, the Left Alliance has been able to renew its support base better than the Social Democrats. The National Coalition has probably benefited the most from the changes occurring in Finland's economic structure and its ramifications for the world of work. The party's support has remained relatively steady in recent parliamentary elections.

The National Coalition's rather stable support has had a lot do with the fact that better-off groups vote more actively than people with lower socio-economic status. Finland has good register-based data and findings about this (Wass 2008; Lahtinen et al. 2017). This fact has also limited the electoral support for the Finns Party. The Greens also suffer much from the low turnout of their young 
supporters, even though many of them are well educated. A register-based study of the turnout differences between age groups reveals that at the 2015 parliamentary election, the turnout of under 25-year-olds was more than 20 percentage points lower than the turnout for the electorate as a whole (Wass \& Borg 2016).

In light of tables 2 and 3, and the pooled polling data from March to May 2019, the potential for much more dramatic changes in party support clearly exists in Finland. If Finland had had the high turnout rate of Sweden or Denmark, the electoral 'bang' might have already been much greater and louder than it has been over the last decade.

Bibliography

Arter, D. 1999. From Class Party to Catchall Party?: The Adaptation of the Finnish Agrarian-Center Party. Scandinavian Political Studies, 22(2), pp. 157-179

Arter, D. 2015a. Democracy in Scandinavia. Consensual, Majoritarian or Mixed? Manchester: Manchester University Press.

Arter, D. 2015b. Scandinavian Politics Today. Manchester: Manchester University Press.

Finnish democracy indicators. A website maintained in cooperation by the Finnish Election Study Consortium and by the Finnish Social Science Data Archive. [ https://www.vaalitutkimus.fi/fi/ ]

Gallagher, M., Laver, M., \& Mair, P. 2011. Representative government in modern Europe. Boston: McGraw-Hill.

IDEA 2019. Voter turnout database of the international IDEA. [ https://www.idea.int/datatools/data/voter-turnout] (Read in June 6, 2019) 
Karvonen, L. 2014. Parties, governments and voters in Finland : politics under fundamental societal transformation. Colchester: ECPR Press.

Lahtinen, H, \& Wass, H. \& Hiilamo, H. 2017. Gradient constraint in voting: The effect of intragenerational social class and income mobility on turnout. Electoral Studies 45(1), 14 - 23.

Paloheimo, H. 2008. Ideologiat ja ristiriitaulottuvuudet. In Heikki Paloheimo ja Tapio Raunio (eds.): Suomen puolueet ja puoluejärjestelmä. Helsinki: WSOY Oppimateriaalit, pp.. 27-59.

Pesonen, P. \& Riihinen, O. 2002. Dynamic Finland. The Political System and the Welfare State. Helsinki : Finnish Literature Society.

Statistics Finland. 2019. Parliamentary elections 2019, result of the control calculation. Helsinki: Statistics Finland. [https://www.stat.fi/til/evaa/2019/evaa_2019_2019-04-24_tie_001_en.html] (Read in June 3, 2019).

Wass, H. 2008. Generations and turnout. The generational effect in electoral participation in Finland. Acta Politica 35. Helsinki: Department of Political Science, University of Helsinki.

Wass, H. \& Borg S. 2016. Yhdenvertaisuus äänestyskopissa: äänestysaktiivisuus vuoden 2015 eduskuntavaaleissa. In Grönlund, Kimmo \& Wass, Hanna (eds): Poliittisen osallistumisen eriytyminen - Eduskuntavaalitutkimus 2015. Helsinki: Oikeusministeriö.

Westinen, J. 2015. Cleavages - Dead and Gone? An Analysis of Cleavage Structure and Party Choice in Contemporary Finland. Scandinavian Political Studies, 38:3, 277-300.

von Schoultz, Å. 2018. Electoral Systems in Context: Finland. In Herron E., Pekkanen, R. and Shugart, M. (eds.), Oxford Handbook of Electoral Systems. Oxford: Oxford University Press, pp. 601-626. 
Data sources

FSD3067: Grönlund, Kimmo (Åbo Akademi University) \& Kestilä-Kekkonen, Elina (University of Tampere): Finnish National Election Study 2015 [dataset]. Version 2.0 (2018-07-24). Finnish Social Science Data Archive [distributor]. http://urn.fi/urn:nbn:fi:fsd:T-FSD3067

Taloustutkimus 2019. (See text)

Figure 1. Support for eight political parties (and for their antecedents) in the Finnish parliamentary elections in 1945-2019 (\%)

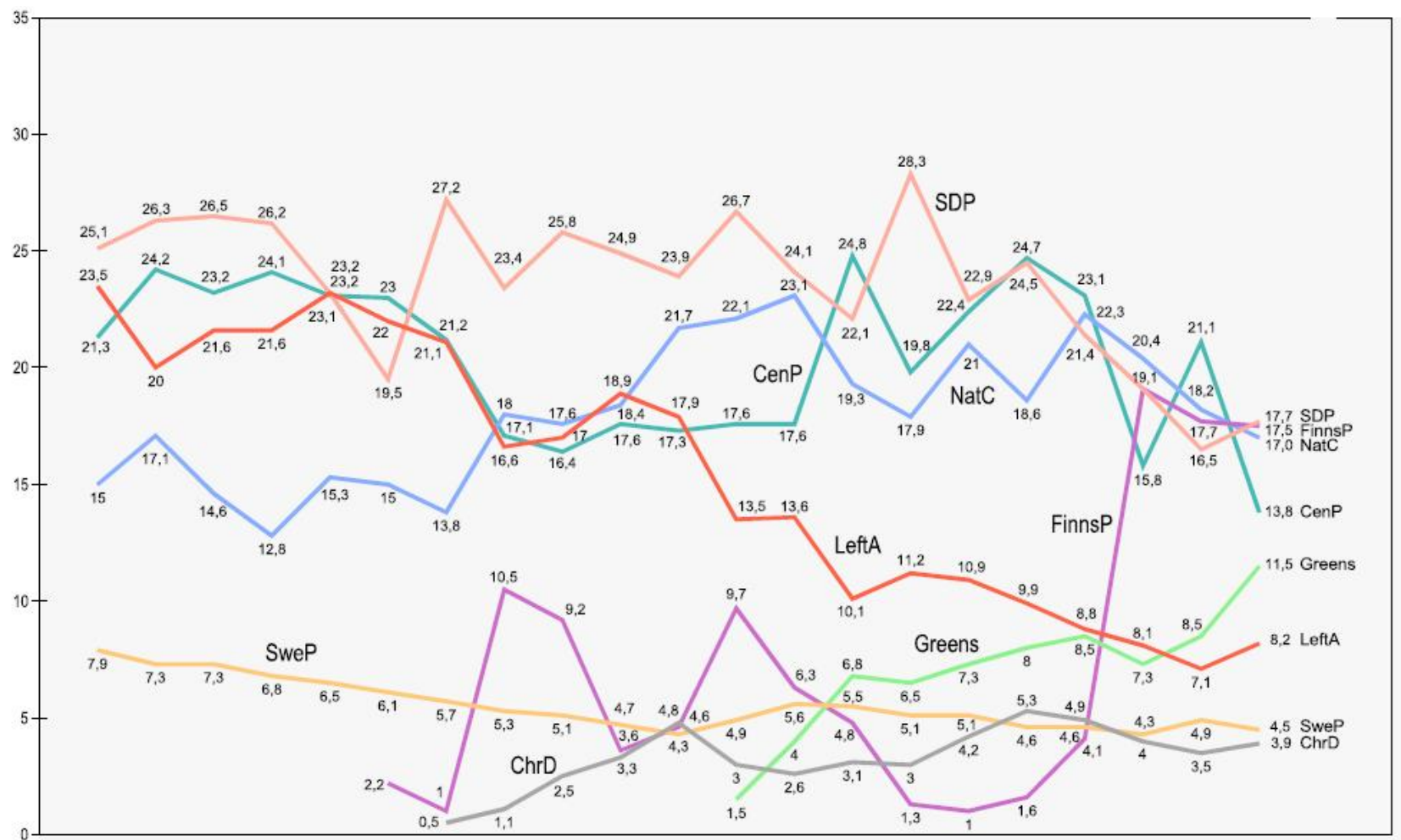

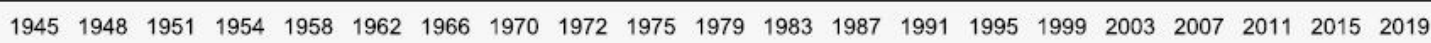

SDP = Social Democrats; FinnsP $=$ Finns Party; NatC $=$ National Coalition; CenP $=$ Centre Party; Greens = Greens; LeftA =Left Alliance; SweP =Finland's Swedish People's Party; ChrP =Christian Democrats. 
Table 1. Results of the 2019 Finnish parliamentary elections: seats, share of votes, and changes from 2015 elections

$\begin{array}{rrr}\text { Political party / group } \quad \text { Seats } \begin{array}{r}\text { Change } \\ 2015-19\end{array} & \% \text { votes } \begin{array}{r}\text { Change } \\ 2015-19^{a}\end{array}\end{array}$

$\begin{array}{lrrrr}\text { Social Democrats (SDP) } & 40 & (+6) & 17.7 \% & (+1.2) \\ \text { Finns Party (FinnsP) } & 39 & (+1) & 17.5 \% & (-0.2) \\ \frac{\text { National Coalition (NatC) }}{\text { Centre Party (CenP) }} & 38 & (+1) & 17.0 \% & (-1.2) \\ \text { Greens (Greens) } & 31 & (-18) & 13.8 \% & (-7.3) \\ \frac{\text { Left Alliance (LeftA) }}{\text { Swedish People's Party (SweP) }} & 20 & (+5) & 11.5 \% & (+3.0) \\ \frac{\text { Christian Democrats (ChrD) }}{\text { Blue Future (splinter from Finns P) }} & 16 & (+4) & 8.2 \% & (+1.0) \\ & 9 & (0) & 4.5 \% & (-0.3) \\ \text { Other political parties } & - & (0) & 3.9 \% & (+0.4) \\ \text { Other groups } & & . & 1.0 \% & . \\ \text { Total } & - & (0) & 2.0 \% & (+0.9) \\ & 2 & (+1) & 2.9 \% & (+2.3)\end{array}$

${ }^{a}$ Difference of votes shares as percentage points.

${ }^{b}$ Includes the MP for the Åland Islands and M P from a non-party list called the M ovement Now (in Finnish Liike Nyt). 
Table 2. The sociodemographic structure of supporters of the Finnish political parties in May 2019 by voters' gender, age group, and level of education (column \%) ${ }^{\text {a }}$

SDP FinnsP NatC CenterP Greens LeftA SweP ChrD Others

\section{Gender}

Women

Men

\section{Age group}

18-24

$25-34$

$35-49$

50-64

65-79 $\begin{array}{lllll}51.1 & 27.3 & 45.6 & 48.7 & \underline{71.7}\end{array}$

$\begin{array}{lllll}48.9 & \underline{72.7} & 54.4 & 51.3 & 28.3\end{array}$

$51.2 \quad 56.1 \quad 68.1$

48.8
34.2

$\underline{65.8}$

\section{Level of education}

$1<10$ years, only basic education $210-12$ years of basic education $3 \mathrm{No} /$ short vocational education 4 Polytechnic 5 Academic

$\begin{array}{rrrrrrrrr}4.7 & 12.5 & 11.4 & 7.5 & 22.1 & 9.3 & 6.7 & 3.8 & 8.2 \\ 12.8 & 20.8 & 17.4 & 12.6 & 20.8 & 23.8 & 10.0 & 13.3 & 32.2 \\ 18.8 & 28.2 & 26.2 & 23.9 & 30.3 & 25.8 & 26.8 & 28.7 & 27.5 \\ 31.8 & 25.8 & 21.4 & 25.8 & 19.2 & 26.0 & 33.2 & 29.7 & 22.8 \\ 31.8 & 12.8 & 23.6 & 30.2 & 7.6 & 15.1 & 23.3 & 24.6 & 8.3\end{array}$

(n)

$\begin{array}{rrrrrrrrr}17.6 & 15.2 & 7.3 & 17.3 & 9.5 & 10.2 & 9.1 & 9.7 & 9.3 \\ 7.5 & 8.4 & 12.1 & 7.3 & 18.6 & 14.5 & 6.7 & 5.2 & 13.2 \\ 48.4 & 59.0 & 28.4 & 45.3 & 18.1 & 41.2 & 28.7 & 39.1 & 34.6 \\ 10.5 & 9.6 & 17.3 & 13.6 & 17.8 & 11.2 & 12.3 & 13.2 & 16.2 \\ 15.9 & 7.8 & 34.7 & 16.3 & 36.0 & 22.9 & 43.2 & 32.4 & 25.6 \\ & & & & & & & & \\ (845) & (811) & (698) & (627) & (810) & (383) & (186) & (153) & (180)\end{array}$

${ }^{a}$ Data Source: In order to get sufficient number of respondents by party and sociodemographic group, the table is based on polling data between M arch 4 - M ay 19, 2019. Telebus data was provided by Taloustutkimus specifically for this article. I thank Juho Rahkonen for his help to produce these results. 
Table 3. Support for the Finnish political parties in M ay 2019 by voters' gender, age group, and level of education (column \%) a

SDP FinnsP NatC CenterP Greens LeftA SweP ChrD Others

\section{Gender}

Women

Men

$\begin{array}{lll}18.6 & 9.3 & 13.9\end{array}$

$13.4 \quad \underline{24.9}$

8.3

$4.5 \quad 4.5$

2.7 (2312)

$\begin{array}{lll}17.5 \quad \underline{24.3} & 16.3\end{array}$

$13.9 \quad 9.7$

$\begin{array}{lll}7.7 & 3.5 & 2.1\end{array}$

5.0 (2381)

\section{Age group}

18-24

$\begin{array}{lll}7.8 & 19.2 & 15.7\end{array}$

$\begin{array}{lll}9.4 & 34.6 & 6.8\end{array}$

$2.5 \quad 1.1$

$2.9 \quad(552)$

25-34

$\begin{array}{lll}13.0 & 19.7 & 14.8\end{array}$

$\begin{array}{lll}9.7 & \underline{20.1} & 10.7\end{array}$

2.2

2.4

$7.2 \quad(825)$

35- 49

$\begin{array}{lll}13.2 & 18.5 & 15.4\end{array}$

$12.7 \quad \underline{20.3}$

8.0

4.2

3.6

4.1 (1173)

50-64

$\begin{array}{lll}\underline{22.6} & 17.1 & 12.7\end{array}$

$13.9 \quad 13.0$

$8.2 \quad 5.2$

3.8

3.5 (1207)

65-79

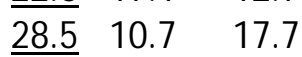

20.5

$6.0 \quad 4.6$

$\begin{array}{lll}4.0 & 1.6 & \text { (936) }\end{array}$

\section{Level of education}

$\begin{array}{lllllllllll}1<10 \text { years, only basic educ. } \underline{25.0} & 20.2 & 8.7 & 18.6 & 12.9 & 6.4 & 2.9 & 2.5 & 2.8 & \text { (586) }\end{array}$

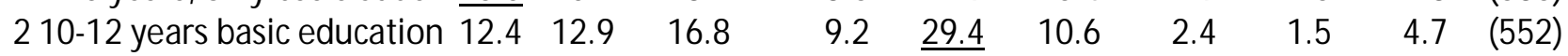

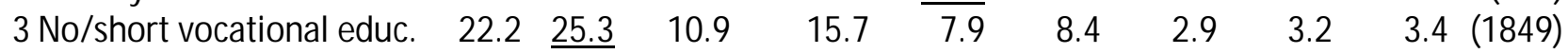

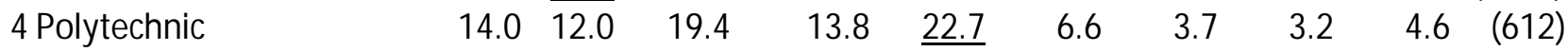
$\begin{array}{llllllllll}5 \text { Academic } & 12.2 & 5.6 & 22.4 & 9.5 & \underline{26.4} & 7.8 & 7.4 & 4.5 & 4.2 \text { (1088) }\end{array}$

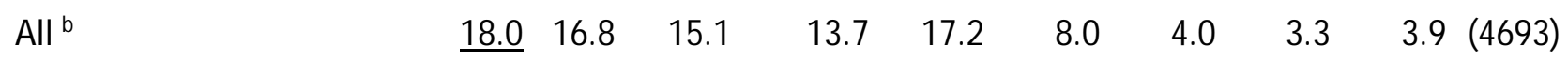

a Data Source: The table is based on extensive polling data collected by Taloustutkimus.

${ }^{b}$ All respondents who reported in the poll which party they would vote, if parliamentary elections were held today. 